\title{
Impact of New Products Development on the Profitability of Nigerian Deposit Money Banks
}

\author{
Marcus Garvey Orji ${ }^{1}$, Ruth Andah ${ }^{2}$, Chima Kate ${ }^{3}$, Abba Solomon Boman ${ }^{4}$ \\ ${ }^{1}$ Department of Business Administration, Veritas University, Abuja, Nigeria \\ ${ }^{2}$ Department of Business Administration, Nasarawa State University, Keffi, Nigeria \\ ${ }^{3}$ Department of Entrepreneurial Studies, Veritas University, Abuja, Nigeria \\ ${ }^{4}$ Department of Business Administration, Ahmadu Bello University, Zaria, Nigeria
}

Email address:

marcusorji@gmail.com (M. G. Orji), ruthandah68@gmail.com (R. Andah), chimak@veritas.edu.ng (C. Kate)

To cite this article:

Marcus Garvey Orji, Ruth Andah, Chima Kate, Abba Solomon Boman. Impact of New Products Development on the Profitability of Nigerian Deposit Money Banks. International Journal of Economics, Finance and Management Sciences. Vol. 5, No. 4, 2017, pp. $213-221$. doi: 10.11648/j.ijefm.20170504.12

Received: October 2, 2014; Accepted: October 16, 2014; Published: July 18, 2017

\begin{abstract}
Profitability strategies can only be formulated and implemented when the marketing manager is well informed about the current marketing situation and to a certain degree, anticipate future changes in the potential and new product market. Many commercial or money deposit banks in Nigeria are faced with problems relating to their marketing activities due to lack of adequate knowledge of the prevailing market situation or product performance evaluation. This research study has the objective of assessing the impact of new products development on the profitability of Nigerian deposit money banks. The study is a survey research and Primary and secondary data were applied and formulated hypotheses tested using kendal co-efficient of concordance. The findings of the study revealed that there is a relationship between new product development and profitability in Nigerian deposit money banks, and poor knowledge of the benefits derived from new product innovation is responsible for low rate of profit maximization in banks. Also that new products innovation and developments come as a result of bank's marketing research efforts. The study recommends however that banks should intensify their research efforts to provide timely information on product development and monitor the degree of customer's satisfaction through market situation analysis.
\end{abstract}

Keywords: New Product Development, Profitability, Nigerian Deposit Money Banks

\section{Introduction}

The success of any commercial organization is highly dependent upon the degree to which it is able to satisfy the consumers of its products. The way to ensure this satisfaction is to see that the consumer preferences and needs are determined at the very beginning of the production process. Thus, the end products must satisfy the consumer needs and wants. The financial products of banks consist of those services they rendered which could be exchanged for a price. To understand the concept of banking, we must understand the meaning of bank or banker, because banking is the set of activities which a bank or banker performs. Banking, according to Alabi (2005), is the business of providing services to consumers and businesses. The basic services a bank provides are checking accounts, which can be used like money to make payments and purchase goods and services; savings accounts and time deposits that can be used to save money for future use, loans that consumers and businesses can use to purchase goods and services; and basic cash management services such as check cashing and foreign currency exchange.

But a broader definition of a bank by Falegan (2006) and Ejiogu (2012) is any financial institution that receives, collects, transfers, pays, exchanges, lends, invests, or safeguards money for its customers. This broader definition includes many other financial institutions that are not usually thought of as banks but which nevertheless provide one or more of these broadly defined banking services. These institutions include finance companies, investment companies, investment banks, insurance companies, pension funds, security brokers and dealers, mortgage companies, and 
real estate investment trust (Ejiogu, 2012).

For a bank to successfully play its financial role and attain its general objectives of profitability, growth and increased share of the market in today's competitive environment, the innovation and marketing of its new financial products and services has become increasingly necessary. In marketing financial services, the bank must endeavour to create and deliver customer satisfying services at a profit to the bank. The concept of profit in the banking industry can be seen from the perspective of banks being able to increase revenue and minimize cost to stay afloat through the strategies of products innovation, penetration, positioning, low prices and charges, high sales volume, and ability to meet customers claims or demands when due. It is in the light of this that this research work will focus on the impact of new products development on the profitability of Nigerian deposit money banks.

\subsection{Statement of the Problem}

Developing new products that can impact positively on bank profit is a herculean task and a long term process that would come after much patience especially in developing economy as compared to poor economy where the purchasing power of goods and services are greatly enhanced. The problem becomes more compounded when dealing with illiterate and peasant consumers as Nigerian banks have to contend with when there is a new product. Bank managers need to find ways of appealing to prospective customers as well as satisfying their need and achieving organizational goal. These dual objectives are increasingly difficult to achieve in a competitive industry. Good marketing strategies are therefore needed to analyse needs and assess capability of new or existing products to satisfy those needs. Superior sales performance and financial viability of the bank also determine its success in satisfying those needs. And financial viability of a bank can only be determined through her profitability index or ratios over time. Many deposit money banks in Nigeria are faced with problems relating to their marketing activities due to lack of adequate knowledge of the prevailing market situation or product performance evaluation. Profitability strategies can only be formulated and implemented when the marketing manager is well informed about the current marketing situation and to a certain degree, anticipate future changes in the potential and new product market.

\subsection{Research Questions}

This research study will provide answer to the following pertinent questions;

1. Is there any relationship between new product innovation and profitability in Nigerian deposit money Banks?

2. Is there any relationship between new products availability and profitability in Nigerian deposit money Bank?

3. Is there any relationship between the techniques for marketing new products and profitability in Nigerian deposit money Bank?

4. How best can the problem of new product management be solved in Nigerian deposit money Banks?

\subsection{Objectives of the Study}

The main objective of this study is to evaluate the impact of new products development on the profitability of Nigerian deposit money banks.

To achieve the main objective the study will also try to:

(1) To determine whether there is any relationship between new product innovation and profitability in Nigerian deposit money Banks.

(2) To determine whether there is any relationship between new products availability and profitability in Nigerian deposit money Banks.

(3) To determine whether there is a relationship between the techniques for marketing new products and profitability in Nigerian deposit money Banks.

(4) Proffer solutions to the problems of developing and managing new products in Nigerian Banks.

\subsection{Hypotheses of the Study}

For the purpose of this research to be achieved, the following hypotheses will help in verifying the research statement.

HO1: (Null Hypothesis)

There is no significant relationship between new products innovation and profitability of Nigerian deposit money Banks.

$\mathrm{HO} 2$ There is no significant relationship between new products availability and profitability in Nigerian deposit money Banks.

HO3. There is no significant relationship between the techniques for marketing new products and profitability in Nigerian deposit money Banks.

\subsection{Scope of the Study}

Although the banking sector consists of the universal banks and development banks, the study is limited to only Twenty four Commercial/Deposit Money Banks (DMBs) in Nigeria. The study will only examine the marketing operations and the extent of the application of new product innovations by the bank involved, and how this impacted on its profitability between 2007-2013 financial years.

\section{Literature Review}

\subsection{Conceptual Framework}

\subsubsection{New Product Development}

In business and engineering, new product development (NPD) is the complete process of bringing a new product to market (Wong \& Tong, 2012). A product is a set of benefits offered for exchange and can be tangible (that is, something physical you can touch) or intangible (like a service, 
experience, or belief). There are two parallel paths involved in the NPD process: one involves the idea generation, product design and detail engineering; the other involves market research and marketing analysis. Companies typically see new product development as the first stage in generating and commercializing new product within the overall strategic process of product life cycle management used to maintain or grow their market share.

A Product according to Kotler and Keller (2006) is anything that can be offered to a market to satisfy a want or need. Also Akpan (2002) defined a product as a complex of tangible and intangible attributes, including packaging, price, manufacturing and retailers services, which the buyer may accept as offering satisfaction of wants and needs.

An organization's product policy is fundamental to the whole operation of the business. When an organization determines to produce a specific product or group of products, it is the decision which dictates the industry to which it will belong, the market it will serve and the nature and extent of the resources, methods, and techniques it will employ (Akpan, 2002)

Kotler and Keller (2006) opined that they are five product levels and each level adds more customer value and the five constitutes a customer value hierarchy. The fundamental level is the core benefit; the service or benefit the customer is really buying. For instance a hotel guest is buying 'rest and sleep' while a bank customer is buying guidance and custody of his/her fund. At the second level the marketer has to turn the core benefit into a basic product. Thus, a hotel room includes a bed, bathroom, towel, desk and dresser; while a bank hall include vault, desk, air conditioner and counting machines. At the third level, the marketer prepares an expected product, a set of attributes and conditions buyers normally expect when they purchase this product. Hotel guest expect a clean bed, fresh towels and working lamp; while a bank customer expect a clean hall, prompt attendance and politeness. At the fourth level, the marketer prepares an augmented product that exceeds customer expectations. Differentiation arises on the basis of product augmentation. Product augmentation also leads the marketer to look at the user's total consumption system; the way the user performs the tasks of getting and using products and related services. At the fifth level stands the potential product which encompasses all the possible augmentations and transformations the product or offering might undergo in the future. Here is where companies search for new ways to satisfy customers and distinguish their offer. This leads to new product innovations as in the case of banks.

New product development according to Ejiogu (2012) is the total efforts by the marketing Executives add another variety to already existing products and services base on envisioned need of customers. In this regards when banks introduced new variety of services to attract customers patronage, a new product is born.

\subsubsection{Profit}

In neoclassical microeconomic theory, the term profit has two related but distinct meanings. Economic profit is similar to accounting profit but smaller because it reflects the total opportunity costs (both explicit and implicit) of a venture to an investor (Albrecht, 1983). Normal profit refers to a situation in which the economic profit is zero. A related concept, sometimes considered synonymous to profit in certain contexts, is that of economic rent.

In Classical economics and Marxian economics, profit is the return to an owner of capital goods or natural resources in any productive pursuit involving labor, or a return on bonds and money invested in capital markets (Carbaugh, 2006). By extension, in Marxian economic theory, the maximization of profit corresponds to the accumulation of capital, which is the driving force behind economic activity within the capitalist mode of production. Other types of profit have been referenced according to Carbaugh (2006), including social profit (related to externalities). It is not to be confused with profit in finance and accounting, which is equal to revenue minus only explicit costs, and superprofit, a concept in Marxian economic theory Profit may be expressed as the proportion by which the price per unit sold exceeds its cost that is, as a rate on turnover. Profit as generally understood, is the difference between the total expenses incurred in producing or acquiring a commodity and the total revenue accruing from sales. This difference may be expressed in a return on capital, the total profit over a year being related to the amount of capital employed. Although profit is a reward to one of the factors of production, it differs in several respects from the income payable to the other factors. Profit is a residual reward payable to the entrepreneurs after all the other costs of the business have been met, where as labour can be certain of its weekly wage or monthly salary, and the debenture holder fairly certain of his interest, there is no guarantee that the ordinary shareholder will receive a dividend.

According Dereck (2001), although profit in accounting sense is a residual payment to capital, but the economists regard it as a cost that has to be met if the firm is to stay in business. While the firm may survive one year and perhaps two without making a profit, it will in the long run go out of business if it cannot pay a dividend to its shareholders. In the case of a bank it may be declared distressed and license withdrawn. Profit differs from other kinds of income in three ways (Dereck; 2001); Firstly, it may be negative. Neither wages, nor interest are ever likely to be negative but every year there are some firms which make a loss and there are few firms which do not make a loss at some time or another. Secondly, profit fluctuates more than any other kind both in boom and slump, there is comparatively change in wage rates, in interest rates or in rents, the burnt of the change falls on profit. Profit responds immediately to a change in price, order incomes are adjusted more slowly and less violently. Thirdly, and this is the crucial distinction according to (Dereck 2001), profit is not like other kinds of income, a contractual and certain income agreed on in advance, but an uncertain residue determined by luck of events. A man's wage, for example, is predetermined and certain in amount, but the income of his employer is not. The man is paid now 
for goods produced, in anticipation of further demands, and since the future can never be foreseen, with certainty, the goods which the employer obtains for a given wage payment are of uncertain value. If eventually the price which the goods realize exceeds the cost incurred in their production, the employer will make a profit. This is where the concept of profitability applies. If on the other hand the selling - price turns out to be lower than the cost which he has incurred, he will make a loss. But he does not, and cannot know in advance that he will be able to make a profit. He certainly expects to make a profit, but he may be unlucky.

\subsection{New Product Development Process}

According to Ejiogu (2012) the major process in developing new products by Nigerian Banks is differentiated products. In this regard customers are differentiated according to their perceived needs and economic class, then a product is designed to meet those needs. The process starts by marketing research, need identification, evaluation of expected profit or cost/profit determination for the new product and management decision. But there have been a number of approaches proposed for analyzing and responding to the marketing challenges of new product development. Two of these are the eight stages process of Koen and a process known as the fuzzy front end (Wong \& Tong, 2012). The eight stages are;

1. Idea Generation is often called the "NPD" of the NPD process.

Ideas for new products can be obtained from basic research using a SWOT analysis (Strengths, Weaknesses, Opportunities \& Threats). Market and consumer trends, company's R\&D department, competitors, focus groups, employees, salespeople, corporate spies, trade shows, or ethnographic discovery methods (searching for user patterns and habits) may also be used to get an insight into new product lines or product features. Lots of ideas are generated about the new product. Out of these ideas many are implemented. The ideas are generated in many forms. Many reasons are responsible for generation of an idea. Idea Generation or Brainstorming of new product, service, or store concepts - idea generation techniques can begin when one have done opportunity analysis to support his ideas in the Idea Screening Phase (shown in the next development step).

\section{Idea Screening}

The object is to eliminate unsound concepts prior to devoting resources to them. The screeners should ask several questions: Will the customer in the target market benefit from the product? What is the size and growth forecasts of the market segment / target market? What is the current or expected competitive pressure for the product idea? What are the industry sales and market trends the product idea is based on? Is it technically feasible to manufacture the product? Will the product be profitable when manufactured and delivered to the customer at the target price?

\section{Concept Development and Testing}

Here according to Wong \& Tong, (2012 )we develop the marketing and engineering details; Investigate intellectual property issues and search patent databases to determine Who is the target market and who is the decision maker in the purchasing process?; What product features must the product incorporate? What benefits will the product provide? How will consumers react to the product? How will the product be produced most cost effectively? Then we prove feasibility through virtual computer aided rendering and rapid prototyping to determine- What will it cost to produce it? Testing the Concept may involve asking a number of prospective customers to evaluate the idea.

4. Business Analysis

Estimate likely selling price based upon competition and customer feedback

Estimate sales volume based upon size of market and such tools as the Fourt-Woodlock equation which are; Estimate profitability and break-even point

\section{Beta Testing and Market Testing}

Here we produce a physical prototype or mock-up; Test the product (and its packaging) in typical usage situations; Conduct focus group customer interviews or introduce at trade show; Make adjustments where necessary, and produce an initial run of the product and sell it in a test market area to determine customer acceptance.

\section{Technical Implementation}

This involve New program initiation; Finalize Quality management system;

Resource estimation; Requirement publication- Publish technical communications such as data sheets; Engineering operations planning; Department scheduling; Supplier collaboration; Logistics plan; Resource plan publication; Program review and monitoring; Contingencies - what-if planning.

\section{Commercialization (often considered post-NPD)}

Here we Launch the product; Produce and place advertisements and other promotions; Fill the distribution pipeline with product; Critical path analysis is most useful at this stage.

\section{New Product Pricing}

We determine Impact of new product on the entire product portfolio by- Value Analysis (internal \& external); Competition and alternative competitive technologies; Differing value segments (price, value and need); Product Costs (fixed \& variable); Forecast of unit volumes, revenue, and profit. These steps may be iterated as needed. Some steps may be eliminated. To reduce the time that the NPD process takes, many companies are completing several steps at the same time (referred to as concurrent engineering or time to market). Most industry leaders see new product development as a proactive process where resources are allocated to identify market changes and seize upon new product opportunities before they occur (in contrast to a reactive strategy in which nothing is done until problems occur or the competitor introduces an innovation). Many industry leaders see new product development as an ongoing process (referred to as continuous development) in which the entire organization is always looking for opportunities (Wong \& Tong, 2012) 


\subsection{Measuring Profitability in an Organization}

A bank employee wage, for example, is predetermined and certain in amount, but the income of his employer is not. The man is paid now for goods or services produced, in anticipation of further demands, and since the future can never be foreseen, with certainty, the goods and services which the employer obtains for a given wage payment are of uncertain value. If eventually the price which the goods and services realize exceeds the cost incurred in their production, the employer will make a profit. This is how the concept of profitability applied, or profitability is measured in an organisation. If on the other hand the selling - price turns out to be lower than the cost which the organization has incurred, it will make a loss. But the organisation does not, and cannot know in advance with $100 \%$ surety that she will be able to make a profit. It certainly expects to make a profit, but may be unlucky (Ejiogu, 2012). Thus, profitability is measured based on the differences between the return on investment and the cost of investment.

\subsection{Strategies for Marketing Financial Products in Nigeria}

Marketing entails the four marketing strategies that are identifying the products, attaching the price, efficient distribution network, and promotion. Marketing can also be looked at as a social process in which the material needs of society are identified, expanded and serviced by a set of institutions. Some decades ago, marketing was solely applicable to goods only and not services and even creating a marketing departments in Banks sounded odd talk-less of employing marketing executive. However, in recent years, banks are becoming marketing conscious.

According to Alabi (2005), the target of marketing bank services and product is to increase the deposit base of the banks and induce the credit worthy customers to borrow at a profit. He further stressed that it is imperative for the banks to market their services, as a result of changes in technology and competition among banks and other financial institutions in Nigeria which has drastically increased with an increasing number of banks branches among universal and merchant banks and unit banking among community or micro-finance banks.

But marketing according to Seborn (2001) is the creation and delivery of customers satisfying services at a profit to the bank. It involves:-

Identifying present and future markets for services.

a Setting long and short term goals for the progress of existing and new services.

b Selecting which market to serve and identifying customers need within them.

c Managing the service so as to persuade customers to use them at a profit and controlling the success in so doing.

It was further stressed that to enable a meaningful strategy to be formulated one has to achieve the following:-The identification of the market, the choice of markets and segment of markets and, the management of resources to service those chosen markets. Long range forecasting has its place in identifying future markets, provided it serves its real purpose, which is to be a basis for realistic planning. Although a bank may identify the best markets within its general field, no bank can serve every market in sight. Every bank has certain constraint and certain strengths and skills which it must recognize. Those will determine in which segment of each market it must leave alone (Onalo; 2004). The strengths and skills include the following:

Strengths- Very large financial resources; High credit standing; Wide credit and commercial network; A branch manager network which gives deep market penetration; A book keeping and money transfer system and International connection.

Skills- Lending in a variety of tenors, e.g. 30 days, 90 days etc; General elementary personal financial advice Cheque processing; Foreign transaction processing; Certain specialties trustees, income tax, etc. Since banks operates in a competitive economy, decisions on a bank marketing mix, are influenced in many ways:- In the period of recession, lending and borrowing always decline. This is because the possibility for business to expand decline, as such savings and borrowing are adequately affected. Onalo (2004) asserted also that socio-cultural environment is another factor affecting banking services. Habits and customs of the people do influence banking services. However, certain section in the United Kingdom feel that whether it is in the period of recession or not, it does affect banking. They also pointed that credit card promotion encourages people to borrow irrespective of the situation as opined by Seborn (2001, in Falegan 2006). Marketing plans are also subject to the constraints of the political and legal environment. The legal need to disclose true lending rate is a recent change, which obviously affects advertising. The need to obtain planning permission to open new branches affects competitive speed and secrecy. Thus, the determination of the marketing strategy is the function of the Chief Executive, whose responsibility is to see that the bank is always properly placed in the business environment. The strategy must provide the best combination of long-term improvement in profitability and stability.

\subsection{New Products Development and Innovation in Nigerian Deposit Money Banks}

While reviewing new product development, Onalo (2004) highlighted the following benefits which are attributed to the growing trend among banks: Enhancement of individual banks corporate image, Bringing banking services nearer to people, showing up capital base of banks due to increased deposits. The various strategies being adopted by the new banks for survival are as many as there are bankers. These include provision of qualitative and prompt services to customers, employing state of the art technology and highly motivated employees in addition to spontaneous response to change in the economy. Others include specialization in specific areas and the packaging of new product and services, 
opening of branches in strategic locations, training and retraining of staff, maintaining contended staff and movement of assets quality through strict control policy. The survival strategies of the deposit money banks have also been reflected in the array of differentiated products and the strong marketing strategies which some have adopted. In fact, Nigerian Banking Industry now abounds with up to 160 new products and services, all packaged to attract customers (Ejiogu, 2012). Some of the banks have two or more of such schemes either in operation or in the pipeline. They forms are designed to out wit even the most shrewd investors. In the same manner, there have been more activities in the money market as banks trade in attractive financial investments. The competition ahead no doubt will task the ingenuity of banks management. Apart from the obvious challenges of how to sustain the level of profits that are being declared, banks must give serious thought to improving both the range and quality of their service with the gradual shrinking of the deposit market, occasioned by low savings rates, the scrambles for deposits is on the upswing among Nigeria Banks. A veritable instrument in this scramble is the introduction of electronic banking products believed to increase efficiency in delivery. Quite a number of them are now in the market and the list includes computers networks, credit cards, smart cards, electronic fund transfer (EFT) and automated teller machines (ATM). The EFT, is however, the vogue in the industry as banks strive to mine the perceived large market for money transfer from Nigerians resident abroad.

\subsection{New Products and Nigerian Deposit Money Bank's Profits}

The choice of target markets by a bank and its decision about developing a product more energetically or cutting a service will depend on profitability of the service or product. Profits depend on market demand, the price at which services can be sold, their cost and competition from other banks and organizations. Competition is a tool for survival and growth through customer satisfaction and product innovation in an economy where the customer has a choice among producers of goods and services. Competition has been fostered by the participation of government in several economic activities, which provided alternative sources to the offers by the private sector. The bank of British West Africa enjoyed a monopoly of the formal banking sector till the coming of its first rival in 1917 (Falegan, 2006). It was however with the commencement of the First banking boom, which incidentally created the basis for competition in the industry. Initially the campaign for customer's fund and the need to sell banking services were valued from two fronts. The early operators saw it as a colonial versus indigenous affair and this manifested itself in their activities. Since the foreign banks were financed and staffed by their foreign head offices, their targets were the government institutions, the businessmen especially the Asians and Lebanese traders and a sprinkling of the locals. On the other hand, the indigenous banks saw the marginalization of local traders from banking/credit facilities as a challenge and an opportunity for competition. The dictates of the 1952 banking ordinance equally lent weight to competition in their direction, commercial banks were restricted to compete along non-price lines as they could not offer differential rates to customers on their deposits. The summary of the foregoing is that- This has intensified competition and has led to a high labour movement within the industry as the new banks have to poach on the established ones for their staff. Different strategies have been adopted to lure customers in all banks Nigerian deposit money banks. Each creates a unique identity, advertises its products and emphasizes the level of modern technology with which its services are rendered. Old products are repackaged, new ones introduced with enticing return on investment. In order to win and retain customer's loyalty and elicit positive response of association from corporate responsibility, unique architectural designs and craftsmanship are now being employed in building and fitting branches and head office of banks (Ejiogu, 2012).

Another weapon of competition, which resulted from deregulation, include the development and employment of various types of financial products and repackaging of existing ones in the same gap by the bankers. These are all aimed at increasing profit. In a nutshell, competition and new product development are the means of achieving bank profit in Nigeria. Although portrayed by developers as instruments of exhibiting they care for the growing fold of banking operators, most banking products have been directed towards shoring up the liquidity base of the commercial banks (Ejiogu, 2012).

\section{Methodology}

This study has been designed in line with survey research using data collected from both primary and secondary sources. The secondary sources comprises of mainly text books, journals and periodicals, while primary source is only from questionnaires. The population for this study comprises of entire staff of 24 Nigerian major licensed Commercial/deposit money banks. Since every member of the population can not be reached, this study selected 100 respondents using judgment random sampling, whereby the researcher uses his/her value judgment to select respondents from the population whose opinions the researcher feels relevant to make a valuable decision (Smith, \& Albaum, 2010). Questionnaires were administered randomly in different money deposit banks in four Nigerian cities of Abuja, Lagos, Kaduna and Benin, and 82 were returned valid representing $82 \%$, which is valid enough to form opinion. The techniques employed to analyse data for this study are the simple descriptive percentage method and Chi-square method derived from kendall coefficient of concordance. The percentage is for the comparisms of respondents that responded for or against a particular question in relation to the over all respondents expressed as a percentage in order to see the pattern of response. The kendall coefficient of concordance method is used in testing a hypothesis 
concerning the differences between a set of observed frequencies of a sample and a corresponding set of expected or theoretical frequencies. It is represented by the following formula:

$$
\mathrm{W}=\frac{12 \sum(\mathrm{Ri}-\check{\mathrm{R}})^{2}}{\mathrm{~K}^{2}\left(\mathrm{~N}^{3}-\mathrm{N}\right)}
$$

Where $\overline{\mathrm{K}}=$ Number of Respondents; $\mathrm{N}=$ Number of weighted questions; $\mathrm{R}=$ Mean; $\mathrm{W}=$ Kendal coefficient of concordance.

$$
\mathrm{X}^{2}=\mathrm{K}(\mathrm{N}-1) \mathrm{W} ; \mathrm{X}^{2}=\text { Chi-square }
$$

The Ninety - Five (95\%) confidence level was used, Where computed value is greater than critical value at 0.05 level of significance, the null hypothesis was rejected and alternative accepted and vice versa (Siegel, 1986). Weights were assigned using likert scale as follows: Strongly Agree4, Agree 3, Disagree 2, Strongly Disagree 1, Undecided 0. The method used for analysis of this research is justified on the reason that, Kendal coefficient of concordance allows all relevant questions in the questionnaire to be part of the test and result. (Seigel, 1986). This position buttressed by Siegel (1986) is also statistically straight-forward.

\section{Results/ Findings}

Table 1. Kendal coefficient of concordance.

\begin{tabular}{lllll}
\hline S/No & Strongly Agree & Agree & Disagree & Strongly Disagree \\
\hline Weight & 4 & 3 & 2 & 1 \\
Question 6 & 40 & 35 & 5 & 2 \\
Question 7 & 35 & 40 & 5 & 2 \\
Question 8 & 35 & 40 & 5 & 2 \\
Question 9 & 20 & 52 & 5 & 5 \\
Question 10 & 35 & 40 & 2 & 5 \\
\hline
\end{tabular}

Source: Field Survey, 2014

Each cell of Respondents was multiplied by the weight assigned e.g. $40 \times 4$ $=160$

\begin{tabular}{|c|c|c|c|c|c|c|c|}
\hline S/No & Strongly Agree & Agree & Disagree & Strongly Disagree & $\mathbf{R i}$ & $\mathbf{R i}-\overline{\mathbf{R}}$ & $(\mathbf{R i}-\overline{\mathbf{R}})^{2}$ \\
\hline Weight & 4 & 3 & 2 & 1 & - & - & - \\
\hline 1 & 160 & 105 & 10 & 2 & 277 & 8.8 & 77.44 \\
\hline 2 & 140 & 120 & 10 & 2 & 272 & 3.8 & 14.44 \\
\hline 3 & 140 & 120 & 10 & 2 & 272 & 3.8 & 14.44 \\
\hline 4 & 80 & 156 & 10 & 5 & 251 & -17.2 & 295.84 \\
\hline \multirow[t]{2}{*}{5} & 140 & 120 & 4 & 5 & 269 & 0.8 & 0.64 \\
\hline & & & Total & & 1341 & & 402.8 \\
\hline
\end{tabular}

Table 2. Endal Coeficient of Concordance.

Source; field survey, 2014

$$
\begin{gathered}
\mathrm{Ri}=\text { Addition of Rows } \\
\overline{\mathrm{R}}=\text { Mean }=\frac{\left(\sum \mathrm{Ri}\right)}{\mathrm{N}}=\frac{1314}{5}=268.2 \\
\mathrm{~W}=\frac{12 \sum(\mathrm{Ri}-\mathrm{R})^{2}}{\mathrm{~K}^{2}\left(\mathrm{~N}^{3}-\mathrm{N}\right)} \\
\mathrm{W}=\frac{12(402.8)}{4^{2}\left(5^{3}-5\right)}=\frac{4833.6}{16(125-5)}=\frac{4833.6}{1920}=2.52 \\
\mathrm{X}^{2}=\text { Chi-square }=\mathrm{K}(\mathrm{N}-1) \mathrm{W} \\
=4(5-1) 2.52 \\
=16 \mathrm{X} 2.52 \\
=40.32
\end{gathered}
$$

\section{Decision}

Based on the above, the decision rule is to reject the Null Hypothesis (Ho) and accept the Alternative hypothesis since the calculated $\mathrm{X}^{2}(40.32)$ is greater than the tabulated (24.99). The tabulated $x^{2}$ was arrived at by determining the degree of freedom.

The degree of freedom $(\mathrm{df})=(\mathrm{c}-1)(\mathrm{r}-1)$

$$
\mathrm{C}=\text { Column total of observed value }
$$

df at specified level of significance at $0.05=24.99$ (Fisher and Yates, 1974, in Ejiogu 2012). Therefore, we reject the Null Hypothesis at 95\% confidence level and critical value of $0.05 \%$ level of significance. This means that;

1. There is a relationship between new product innovation and profitability in Nigerian deposit money Banks.

2. There is a relationship between new products availability and profitability in Nigerian deposit money Banks.

3. There is a relationship between the techniques for marketing new products and profitability in Nigerian deposit money Banks

4. Banks profitability is measured in terms of revenue increase and cost decrease.

5. New product innovation and development is as a result of bank's marketing research efforts.

6. Poor knowledge of the benefits derived from new product innovation and development is responsible for low rate of profit maximization in Nigerian deposit money banks.

Six decisions were arrived at because of the nature of the statistical tool used. As stated earlier Kendal coefficient of 
concordance allows all relevant questions in the questionnaire to be part of the test results hence answering them and making them part of the decision.

\section{Conclusion}

This study draws its conclusion base on the findings that the inability of banks to actively involve in marketing research hampers their new product innovation and development efforts. And the poor knowledge of the benefits derived from new product innovation is responsible for low rate of profit maximization in banks.

\section{Limitations}

There were some limitations in this study which may need to be addressed in future research. One of the limitations of the study is the low response rate, which unfortunately lessens the generalisability of the findings to the entire population of Nigerian banks. Also the researcher found it a little bit difficult getting the attention of the bankers in charged, as some of them were too busy to even attend to the researcher, while some viewed the researcher's request with contempt and suspicious especially with this syndrome of official corporate secrets or classified materials. But, we believe this study will help create an insight on the dynamics as well as the analytical methods of improving financial services decisions in the banking industry through new product innovation.

\section{Recommendations}

Based on the conclusions above, the following are our recommendations.

1. Nigerian deposit money Banks should pay more attention and intensify their research efforts to provide timely information on product development and other areas of their operation.

2. In line with the above, Nigerian deposit money Banks should strive to monitor the degree of customer's satisfaction with their services on a continuous basis through market situation analysis. This way, the banks will be able to see areas requiring improvement thereby facilitating the much-desired satisfactory delivery of financial services and profit maximization.

3. Diversification of product line in banks will reduce cost and increase profit, so banks should diversify their product line.

\section{Appendix}

\section{Questionnaire}

Section One

Please mark " $X$ " against your appropriate choice

1. Sex: Male [ ] Female [ ]

2. Marital Status: single [ ] Married [ ]

3. Qualification: Master Degree [ ]B.sc [ ] Diploma [ ]
School cert. [ ]

4. Age: 20 - 30 years [ ] (b) 31-40 years [ ] (c) Above 40 years [ ]

5. Length of service: (a) 1-5yrs [ ] 6-10 years [ ] (c) 1115 years [ ]

6. above 15 years [ ]

Section Two

Please indicate the extent of your views by answering the following and selecting either of the alternatives.

Just mark "X" against your choice. Strongly Agree = SA, Agree $=\mathrm{A}$, Undecided $=\mathrm{UD}$, Disagree $=\mathrm{D}$, Strongly disagree $=\mathrm{SD}$

$\begin{array}{ll}\text { S/No } & \text { QUESTIONS } \\ & \text { Profitability is } \\ & \text { measured in terms of } \\ & \text { revenue increase and } \\ \text { cost decrease in your } \\ \text { bank? } \\ \text { New products } \\ \text { availability } \\ \text { significantly increases } \\ \text { profitability in your } \\ \text { Bank Plc? } \\ \text { New product } \\ \text { innovation and } \\ \text { development } \\ \text { significantly increases } \\ \text { profitability in your } \\ \text { Bank? } \\ \text { Development of } \\ \text { quality products by } \\ \text { your bank is as a result } \\ \text { of effective marketing } \\ \text { efforts? } \\ \text { The techniques for } \\ \text { marketing new } \\ \text { products significantly } \\ \text { increase profitability in } \\ \text { your Bank? }\end{array}$

\section{References}

[1] Akpan. A. B; (2002) Marketing Strategy Concept and Application Isola Ola and Sons Zaria.

[2] Alabi, T. A (2005) "Marketing of banking services in Nigeria" University Press Ilorin.

[3] Albrecht, W. P. (1983). Economics. Englewood Cliffs, New Jersey: Prentice-Hall.

[4] Busch, S. P (1985): 'Marketing, Strategic Foundation', Richard D. Irwn, Inc. Homewood, Illinois.

[5] Carbaugh, Robert J. (January 2006). Contemporary economics: an applications approach. Cengage Learning.

[6] Dereck, j. (2001) Introduction to Economics; 3rd edition; Butterworth and Co. publishers Ltd London. 
[7] Ejiogu, O (2012) Assessment of the influence of new product development on profitability in Nigerian Banks. Unpublished MBA project. Department of business administration, A. B. U, Zaria.

[8] Falegan, S. B (2006) "Redesigning Nigeria's Financial System" University Press PLC, Ibadan.

[9] Kolter, P and Keller, B; (2006): "Marketing Management" 12th edition, Prentice - Hall, Inc, Englewood Cliff New Jersey.

[10] Onalo, J (2004) Effects and Roles of Marketing Concepts on Corporate Performance; A study of some financial Institutions in Nigeria. MBA Project, Department of business Administration. A. B. U Zaria.
[11] Onu, A. J. C (2000): "Marketing Today" Precious Treasures Limited, Abuja.

[12] Smith, S. M \& Albaum G. S (2010) An Introduction to Marketing Research, Sage Publishers, NY, P 129.

[13] Stanton, W. J (1981): "Fundamental of marketing" 6th edition, McGraw Hill book company, New York.

[14] Wong, S. K. S. and Tong, C. (2012), "The influence of market orientation on new product success", "European Journal of Innovation Management", Vol. 15 No. 1, pp.99- 121.

[15] www.firstcitygroup.com; accessed 16/4/2014.

[16] www.Skyebank.com accessed 16/4/2014. 